\title{
Evaluation of affecting factors and the effectiveness of treatment in cases with post-dural puncture headache who underwent epidural blood patch
}

\author{
Epidural kan yaması uygulanan dural-ponksiyon sonrası başağrısı \\ olgularında etkileyen faktörler ve tedavi etkinliğinin değerlendirilmesi
}

Lütfiye PIRBUDAK, ${ }^{1}$ Mete Gürol UĞUR, ${ }^{2}$ Berna KAYA UĞUR, ${ }^{3}$ Seval KUL, ${ }^{4}$ Süleyman GANIDAĞLI ${ }^{1}$

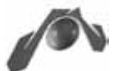

Summary

Objectives: We evaluated post dural puncture headache (PDPH) cases and the contributing factors and monitored the treatment response with epidural blood patch (EBP), and other therapies.

Methods: In this retrospective study, 77 PDPH cases treated with EBP were included. Patients were evaluated in terms of age, gender, type of surgery, type and diameter of the needle used for dural puncture, number(s) of dural puncture, onset of punctural headache, any conservative therapies for PDPH, number(s) of EBP application, analgesia quality at the 10th minute and 2nd hour after EBP application, and radicular pain during procedure.

Results: The mean age of 77 patients ( 46 female, 31 male) was $31.5 \pm 11.3$, and the most common surgery performed was cesarean section. More than one attempt was applied in 48 patients. In 37 cases, a $22 \mathrm{G}$ spinal needle was used, while a $25 \mathrm{G}$ spinal needle was used in 20 cases. The mean duration of the headache was $3.1 \pm 1.3$ days for female patients and $4.6 \pm 2.3$ days for male patients $(p=0.020)$. VAS significantly decreased and patient satisfaction significantly increased after the 10 th minute in patients who had EBP $(\mathrm{p}=0.001)$. In only one case $(2 \%)$, the second EBP was needed for pain relief. Transient radicular pain was observed in 17 cases $(22.07 \%)$ at administration of EBP.

Conclusion: In PDPH cases, EBP is an effective and relatively safe method, especially in obstetric patients. We reported that the PDPH symptoms presented earlier in female patients. A preference of a small diameter needle (less than $22 \mathrm{G}$ ) and avoidance of multiple attempts is important for spinal anesthesia.
\end{abstract}

Key words: Epidural blood patch; post dural puncture headache; radicular pain; surgery.

\begin{abstract}
Özet
Amaç: Dural ponksiyon sonrası baş ağrısı (DPSB) olguları, katkıda bulunan faktörler, epidural kan yaması (EKY) tedavisi ve tedaviye yanıtları değerlendirildi. Bu çalı̧mada amacımı EKY uygulanan DPSB olguların incelemektir.

Gereç ve Yöntem: Bu geriye dönük çalı̧̧mada, EKY uygulanmak suretiyle tedavi edilen 77 DPSB olgusu dabil edildi. Olgular yaş, cinsiyet, geçirilen operasyonun tipi, kullanılan iğnenin tipi ve çapı, spinal girişim sayısı, EKY uygulaması sırasında radiküler ağrı, sonrasında analjezi kalitesi ve olgu memnuniyeti açısından değerlendirildi.

Bulgular: Yetmiş yedi olgunun (46 kadın, 31 erkek) yaş ortalamas $31.5 \pm 11.3$ ve en yaygin yapılan cerrabi sezaryan idi; 48 olguda birden fazla girişim yapılmıştı, 37 olguda 22 G, 20 olguda 25 G spinal iğne kullanılmıştı. Baş ağrısı süresi kadın hastalarda orta-

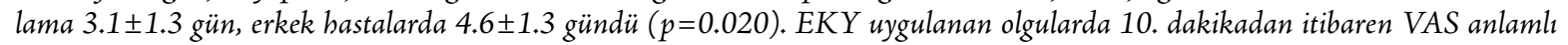
derecede azalırken, olgu memnuniyeti anlaml olarak arttı ( $p=0.001)$. Sadece bir (\%1.29) olguda iki defa EKY'ye ibtiyaç duyuldu. Geçici radiküler ağr EKY yönetiminde 17 olguda (\%22.07) oldu, ancak 5-10 dk içinde geriledi.

Sonuç: DPSB'li olgularda EKY özellikle obstetrik olgularda etkin ve güvenilirdir. DPSB semptomlarının kadın bastalarda daba erken görüldü̈̆̈̈nü saptadik. Spinal anestezi uygulamalarında 22 G’den daba küçük çapl iğneler tercib edilebilir ve birden çok denemeden özenle kaçınılabilir.
\end{abstract}

Anahtar sözcükler: Epidural kan yaması; dura ponksiyonu sonrası baş ağrısı; radiküler ağrı; cerrahi.

\footnotetext{
'Department of Anesthesiology and Reanimation, Division of Algology, Gaziantep University Faculty of Medicine, Gaziantep, Turkey; ${ }^{2}$ Department of Obstetrics and Gynecology, Gaziantep University, Faculty of Medicine, Gaziantep, Turkey;

${ }^{3}$ Department of Anesthesiology and Reanimation, Gaziantep Childrens' Hospital, Gaziantep, Turkey;

${ }^{4}$ Department of Biostatistics, Gaziantep University Faculty of Medicine, Gaziantep, Turkey

'Gaziantep Üniversitesi Tıp Fakültesi, Anesteziyoloji ve Reanimasyon Anabilim Dalı Algoloji Bilim Dalı, Gaziantep;

${ }^{2}$ Gaziantep Üniversitesi Tıp Fakültesi, Kadın Hastalıkları ve Doğum Anabilim Dalı, Gaziantep;

${ }^{3}$ Gaziantep Çocuk Hastanesi, Anesteziyoloji ve Reanimasyon Kliniği, Gaziantep;

${ }^{4}$ Gaziantep Üniversitesi Tıp Fakültesi, Biyoistatistik Anabilim Dalı, Gaziantep
}

Submitted (Başvuru tarihi) 07.08.2012 Accepted after revision (Düzeltme sonrası kabul tarihi) 24.07.2013

Correspondence (illetişim): Dr. Lütfiye Pirbudak. PTT Üniversite Şubesi, P.K. 43, 27310 Gaziantep, Turkey.

Tel: +90 - 342 - 3606060 / 77805 e-mail (e-posta): lutfiyep@hotmail.com 


\section{Introduction}

Post dural puncture headache (PDPH) is stil a considerable problem concerning anesthesiologists although it has been more than 100 years since its definition. It is one of the most common complications of neuroaxial anesthesia. ${ }^{[1]}$

PDPH was recognised after first spinal anesthetic in 1898 by Bier and his surgical resident Hildebrandt, who performed spinal anesthesia on each other. ${ }^{[2]}$ There has been a significant decrease in the incidence of PDPH after the improvement of the pencil-point needles by Whitacre in 1951. Epidemiology, pathophysiology, clinical symptoms and treatment has improved since earlier 1898 ' $^{.[2]} \mathrm{PDPH}$ is seen approximately $40 \%$ of the cases in which has dural perforation. Headache typically occurs $24-48$ hours after the procedure and lasts for approximately 12 days. In some cases it has been reported that duration of headache lasts for months or even for more than a year. The headache in PDPH cases were localised to the frontal region, sometimes spreaded to occipital region, or both. In addition patients complain of nausea-vomiting, auditive and ocular symptoms, including tinnitus, vertigo, diplopia. The clinical statement sometimes can be accompanied by stiffness of neck and regional paresthesia. ${ }^{[3]}$

Conservative therapy and bed rest is the first choice of therapy in PDPH. Treatments include caffeine, paracetamol, sumatriptan and adrenocorticotropic hormone, but there is little evidence to support their use. Appling epidural saline, blockadge of occipital nerve, normobaric and hyperbaric oxygen therapy, epidural dextrane, placing subarachnoid catheter are the alternative choice of therapy. Autologous epidural blood patch (EBP) which was first described by Gormly in 1960 is the most effective therapy in patients who do not respond to conservative therapy. ${ }^{[2-4,5]}$

In this study we evaluated the PDPH cases that underwent EBP, who were referred to Algology Clinic of Gaziantep University School of Medicine, and their response to the therapy retrospectively.

\section{Materials and Methods}

Seventy-seven PDPH cases who were referred to the
Algology Clinic of Gaziantep University, School of Medicine, Department of Anesthesiology and Reanimation from 5 different hospitals and treated with EBP between February 2002 and May 2012 were included in the study. Approval of the Institutional Review Board was obtained from the Faculty Ethical Commitee.

Diagnostic criteria of International Headache Society for PDPH is admitted as inclusion criteria as follows:

'Headache that worsens within 15 minutes after sitting or standing and improves within 15 minutes after lying, with at least one of the following and fullfilling criteria; neck stiffness, tinnitus, hyperacusia, photophobia, nausea and headache develops within 5 days after dural puncture'. ${ }^{[4]}$

In our clinic the routine procedure of PDPH treatment consists of bed rest (and/or intravenous hydration, laxatives, paracetamol and caffeine, oral caffeine drinks. EBP is performed to severe PDPH cases (VAS>8) who do not respond to the conservative therapy.

Cases who referred to our clinic are informed to the EBP therapy after taking detailed medical history and performed a physical examination. after routine monitorisation (non-invasive blood pressure, periferic oxygen saturation and heart rate) EBP was EBP was performed at the same space as the previous spinal or epidural if possible. Once epidural is in place with 18G Touhy needle via loss of resistance technique, $15-20 \mathrm{ml}$ of blood is withdrawn from the forearm. The blood is carefully and aseptically transferred to the anesthesiologist who injects it slowly (approximately in 10 seconds ) through the epidural needle. Before injecting autologous blood to the epidural space, $25 \mu \mathrm{g}$ of fentanyl was injected for proving rapid analgesia. ${ }^{[6]}$ Phlebotomy was first performed at the same time epidural space was first identified to avoid coagulation. The procedure continued since 15-20 $\mathrm{ml}$ of autologous blood was injected totally or since low back pain, neck pain, radicular pain spraded to legs or worsening headache occurs.

After the procedure, patients had routinely had bed rest in supine position for 2 hours while rou- 
tine vital monitorisation is continued. Patients are evaluated clinically for intensity of headache and radicular pain with Visual Analog Scale (VAS) (0$10 \mathrm{~cm}, 0=$ no pain, $10=$ most severe pain ever felt) before procedure, 10 minutes after procedure at supine position and 2 hours after procedure at sitting position. Analgesia quality was evaluated and interpreted by both patient and anesthesiologist (perfect, good, enough, poor, bad).

Patients are evaluated for age, gender, type of the surgical operation performed previously, type and diameter of the needle used for dural puncture, number of dural puncture, onset of punctural headache, conservative therapies taken before for PDPH, number of application of EBP, analgesia quality 10 minutes and 2 hours after EBP application, radicular pain during procedure. Patients who have persistant PDPH after 48 hours of procedure second EBP is performed.

Repeated measures analysis of variances was used when the same parameter has been measured at more than two different times. Comparison of independent proportions and independent groups were performed by fisher exact test and student $t$ test, respectively. Mean \pm standart deviation, frequencies and percentages were given as descriptive statistics. Analyses were performed using SPSS for windows version 11.5 and a $\mathrm{p}$-value $<0.05$ was considered as significant.

\section{Results}

Mean age of 77 patients ( 46 female, 31 male) was $31.5 \pm 11.3(\min 17, \max 53)$. There was a statistically significant difference between the groups in terms of gender $(\mathrm{p}<0.05)$. The patients were mostly referred from the obstetrics and gynecology clinic and 31 of them underwent a cesarean section (Table 1) and the distribution of obstetric and non-obstetric cases was not significant ( $p>0.05)$.

All PDPH patients were treated conservatively at first (including bed rest, oral and/or intravenous hydration, paracetamol and caffeine preparates) during their postoperative follow-up in the clinic which dural puncture was performed. The mean duration of the headache before referring to our Algology clinic was $3.1 \pm 1.3$ days for female patients and 4.6 \pm 2.3 days for male patients $(\mathrm{p}<0.05)$.

Diameter of the needles used in dural puncture were 22G Quincke spinal needle for 37 patients (48.1\%), 25 G Quincke spinal needle for 20 patients (26\%), $26 \mathrm{G}$ Quincke spinal needle for 3 patients $(3.8 \%)$, $27 \mathrm{G}$ Quincke spinal needle for 6 patients $(7.8 \%)$ and $18 \mathrm{G}$ Touhy epidural needle for 11 patients (14.3\%). There was a significant difference between patients who underwent dural puncture with $22 \mathrm{G}$ spinal needle and the other diameters $(\mathrm{p}<0.001)$. The $27 \mathrm{G}$ spinal needle was less commonly used than $25 \mathrm{G}$ spinal needle in PDPH patients in a sig-

Table 1. Distribution of cases according to surgical departments

\begin{tabular}{|c|c|c|}
\hline Surgical departments & $\mathbf{n}$ & Percentage (\%) \\
\hline Obstetrics and gynecology & 43 (obstetric cases $=31$ ) & $55.8 \%$ ( $40.2 \%$ obstetric cases) \\
\hline Orthopedia & 17 & 22.1 \\
\hline Urology & 10 & 13 \\
\hline General surgery & 7 & 9.1 \\
\hline
\end{tabular}

Table 2. Distribution of needle type used for performing epidural blood patch in order to treat post-dural puncture headache cases

\begin{tabular}{lcc}
\hline Type of needle & $\mathbf{n}$ & Percentage (\%) \\
\hline Quincke & 62 & $80.5^{*}$ \\
Tuohy & 11 & 14.3 \\
Pencil-point & 4 & 5.2 \\
\hline
\end{tabular}

${ }^{*} p=0.001$ : When Tuohy ve Pencil-point needles are compared. 
Table 3. Evaluation of analgesic quality

\begin{tabular}{lcc}
\hline & Patient & Anesthesiologist \\
\hline Perfect & $68^{*}$ & $69^{*}$ \\
Good & 9 & 8 \\
Enough & 0 & 0 \\
Poor & 0 & 0 \\
Absent & 0 & 0 \\
\hline
\end{tabular}

* $p=0.001$

nificant manner $(\mathrm{p}<0.05)$. Sharp-edged needles were used in 62 patients $(80.5 \%)$ during dural puncture. Distribution of spinal-epidural needle types used at the first dural puncture were specified in Table 2. There was significant difference between the number of dural puncture attempts as single shot and more than one attempt, 29 patients and 48 patients, respectively $(\mathrm{p}<0.05)$.

Analgesic quality evaluation of EBP is shown in Table 3. VAS significantly decreased and patient satisfaction significantly increased after the 10th minute in all patients who had EBP ( $\mathrm{p}=0.001)$ (Figure 1). Mean VAS scores evaluating analgesic quality before EBP, after 10 minutes and 2 hours after EBP were $9 \pm 0.5(\min 7-\max 10), 1.44 \pm 1.05(\min 0-\max 4)$, $1.2 \pm 0.80$ ( $\min 0$ - $\max 3$ ), respectively.

In 76 cases, PDPH was relieved at first administration of EBP, and in only one case second EBP was needed for pain relief. In this case VAS scores at 10th minute and second hour after EBP were 0 . Success rate of EBP administration at once was $98.7 \%(\mathrm{n}=76)$.

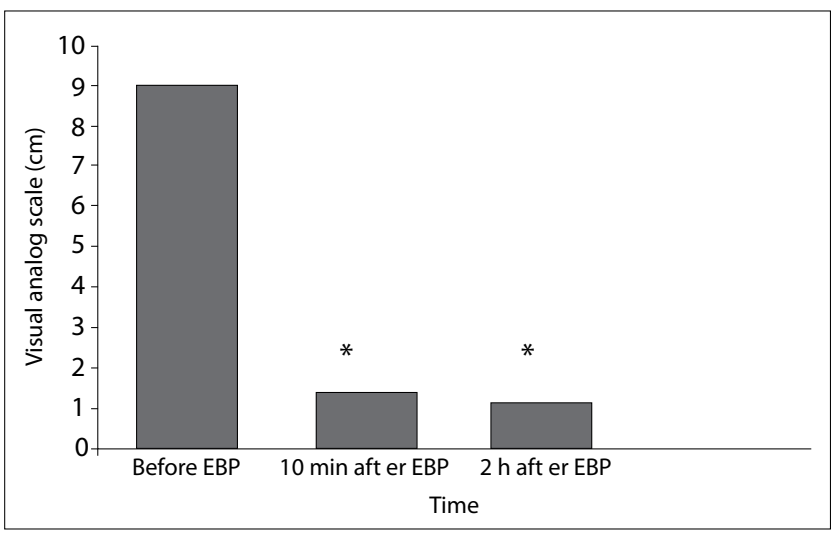

Figure 1. Visual analog scale values before, 10 minutes after and 2 hours after epidural blood patch. ${ }^{*} p=0.001$ : Compared VAS values before after epidural blood patch (EBP).
Transient radicular pain was observed in 17 cases $(22.07 \%)$ at administration of EBP but pain was regressed in 5-10 minutes and none of the patients needed an further medication for pain relief.

\section{Discussion}

In this retrospective study we observed that most of the patients were young and female and most of the patients had more than one attempt with large bore and sharp edge needle. Previous studies were mostly planned as prevalence studies and analyzed the association of the needle size or type and frequency of postspinal headache. But in this study, as a referral center for pain, we analyzed the characteristics of patients and the results of the intervention and treatment. Thus, we reported that the symptoms were presented earlier in female patients.

Factors that effect PDPH are age, gender, pregnancy, needle type, needle diameter and number of attempts. ${ }^{[7]}$

The exact mechanism of headache after dural puncture is unclear. It is most probably due to intracranial hypotension. This explanation is not sufficient. There are two possible explanations: Firstly low cerebrospinal fluid (CSF) volume depletes the cushion of fluid that supports the brain and its sensitive meningeal vascular coverings. This may explain the positional nature of headache. Secondly, decrease in CSF volume may activate adenosine receptors directly causing cerebral vasodilatation and stretching of pain sensitive cerebral structures. ${ }^{[8]}$ In our study $62.3 \%$ of the cases had dural puncture with spinalepidural needles larger than 22G. Multiple attempts, individual differences of dural thickness between patients may play a role in pathophysiology.

Cerebrospinal fluid density may also effect incidence of headache. CSF density is lower in pregnants. ${ }^{[7]}$ Pregnants seems to be keen on PDPH because of facilitating factors like gender, young age, common use of regional anesthesia. ${ }^{[1,5,9]}$ Anatomic changes in pregnancy and presacral edema creates a technical difficulty and its clinical presentation causes multiple attempts. 31(40.2\%) women in our evaluation had $\mathrm{C} / \mathrm{S}$ and this seems to be consistant with the pathophysiology of headache. 
The incidence of accidental dural puncture with Touhy epidural needle is $0.04-6 \%$. PDPH is a complication of epidural analgesia with an incidence of $1-3 \%$. In more than $80 \%$ of these patients develop PDPH. ${ }^{[10]}$ Touhy epidural needle were used in $14.3 \%$ of patients who were performed EBP and this is significantly lower than ratio of patients who were applied dural puncture with $22 \mathrm{G}$ Quincke spinal needle. We can explain this situation that accidental dural puncture with Touhy epidural needle is seldom in our study as published in literature.

Spinal dural thickness has large variations individually and also between patients. Perforation of thicker region of duramater lets CSF leakage lesser (therefore causes less PDPH), so thinner region lets PDPH more. ${ }^{[3,10,11]}$ This may explain the mechanism in PDPH cases which dural puncture had performed at first attempt. However performing dural puncture by experienced practitioners would lessen the incidence of multiple attempts. Furthermore experienced practitioners would perform the procedures with small diameter needles without any technical difficulty.

PDPH is usually a self limited clinical situation. $72 \%$ of cases ceases in 7 days and $87 \%$ of cases in 6 months spontaneously. ${ }^{[12,13]}$ In our study patients referred to our clinic ceased on average 3 days.

Patients typically suffer from positional headache worsens by upright position. In some cases tinnitus, vertigo, nausea-vomiting, photophobia, neck stiffness can be seen. ${ }^{[2,11]}$ Differential diagnosis of PDPH includes other clinical manifestations like nonspecific headache, caffeine withdrawal syndrome, migraine, menengitidis, sinusitis, pre-eclampsia, intracranial pathologies ${ }^{[1,13]}$ and they are eliminated before EBP in our clinic.

Conservative therapy of PDPH consists of oral or intravenous hydration, caffeine and methylxantines. There is no clinical evidence that proves the effectiveness of intravenous hydration in PDPH but patients should not be left dehydrated.

Effectiveness of caffeine is $75-80 \%$ but it is reported that this efffect lasts for only 48 hours. ${ }^{[14,15]}$ Methyxantines provides a transient relief due to their cere- bral vasospasm effect. Failure in conservative therapy is more than $80 \%$ especially in obstetric patients. ${ }^{[14]}$ For all these reasons EBP application becomes to be a method that increasingly gaining popularity.

Effectiveness of EBP application for once is 7098\% in literature. ${ }^{[16]}$ Amount of autologous blood transferred to epidural space is also important. In a multicenter study of Abouleish et al 524 cases in 11 centers were followed up for long term after EBP performed with amount of more than $15 \mathrm{ml}$ and found that it is effective more than $95 \% .{ }^{[15]}$

In some studies it is stated that injecting more than $20 \mathrm{ml}$ of blood at sitting position spreads through approximately 9-10 spinal segment. ${ }^{[6,15,17]}$ Abouleish et al explained there is no benefit of volumes more than $20 \mathrm{ml} .{ }^{[15]}$ Most probably EBP has an acute effect in PDPH by a transient increase in CSF pressure and a permanent effect by clot formation in epidural space that forms an obstruction of dural defect and avoids CSF leakadge. ${ }^{[18]}$ Opioids can curb the symptoms of slight PDPH cases. ${ }^{[8]}$ Most of the authors of case reports or controlled studies notified administration of epidural, intratecal or parenteral opioids. ${ }^{[4]}$ The advantage of administration of intrathecal fentanyl is analgesia with rapid onset without creating motor blockadge. Peak effect can be achieved by $25 \mu \mathrm{g}$ of fentanyl. ${ }^{[6]}$ Before EBP we considered the probablity of intrathecal transition of opioid and administered $25 \mu \mathrm{g}$ of fentanyl to epidural space for increasing the effectiveness of therapy. We also used 15-20 $\mathrm{ml}$ of autologous blood for EBP as similar in literature. Only one case needed 2nd administration of EBP. Headache was completely relieved in this case.

The most common complications seen after EBP are backache (35\%), neckache $(0.9 \%)$, transient fever $(5 \%) \cdot{ }^{[19]}$ Haemorrhage, infection, accidental dural puncture, arachnoiditis caused by blood transferred to subarachnoid region and in only two cases transient facial nerve palsy in only two cases are reported. ${ }^{[20,21]}$ Also tinnitus, vertigo, ataxia, drowsiness, vasovagal syndrom are reported as the other complications. ${ }^{[22]}$

Inadequate amout of autologous blood transferred to epidural space may delay pain relief. However 
EBP performed with excessive blood volumes may induce radicular pain. ${ }^{[19]}$ Radiculopathy is reported at highly excessive blood volumes $(>30 \mathrm{ml})$ and this clinical manifestation improves spontanously in 3-4 months. ${ }^{[23]}$

We observed radicular pain in 17 cases $(22.07 \%)$ lasting for 5-10 minutes after application of 15-20 $\mathrm{ml}$ autologous blood to epidural space and no medical treatment was required. This symptom has not been reported in literature. This present situation can be explained by following reasons. This clinical symptom has a nature with short duration and also recovers spontaneously without further medical treatment so radicular pain can be ignored as an adverse effect. And also injection of blood had been stopped when radicular pain observed. Because of all these reasons radicular pain might be ignored in literature.

Although PDPH cases who do not respond to conservative therapy symptoms regresses in months, pain relief is very important for improving life quality for all groups of patients. Because of this clinical situation deteriorates relationship between mother and baby at postpartum period, EBP is an effective and relatively safe method in obstetric patients. Also we consider that practitioners must be alert on avoiding this clinical situation by using small diameter needles less than $22 \mathrm{G}$ and beware of multiple attempts.

\section{Conflict-of-interest issues regarding the author- ship or article: None declared.}

\section{Peer-rewiew: Externally peer-reviewed.}

\section{References}

1. Kuczkowski KM. Post-dural puncture headache in the obstetric patient: an old problem. New solutions. Minerva Anestesiol 2004;70(12):823-30.

2. McLeod G. Spinal anaesthesia - intradural \& extradural. In: Davies NJH, Cashman JN, editors. Lee's synopsis of anaesthesia. 13th ed. New York: Elsevier; 2006. p. 517-18.

3. Lavi R, Rowe JM, Avivi I. Lumbar puncture: it is time to change the needle. Eur Neurol 2010;64(2):108-13. CrossRef

4. Turnbull DK, Shepherd DB. Post-dural puncture headache: pathogenesis, prevention and treatment. $\mathrm{Br} J$ Anaesth 2003;91(5):718-29. CrossRef

5. Kuczkowski KM, Benumof JL. Decrease in the incidence of post-dural puncture headache: maintaining CSF volume. Acta Anaesthesiol Scand 2003;47(1):98-100. CrossRef

6. Van de Velde M, Schepers R, Berends N, Vandermeersch E, De Buck F. Ten years of experience with accidental dural puncture and post-dural puncture headache in a tertiary obstetric anaesthesia department. Int J Obstet Anesth 2008;17(4):329-35.

7. Ahmed SV, Jayawarna C, Jude E. Post lumbar puncture headache: diagnosis and management. Postgrad Med J 2006;82(973):713-6. CrossRef

8. Kocamanoğlu is, Sarıhasan B, Şener B et al. Methods and complications of anesthesia in cesarean/section operations: retrospective evaluations of 3552 cases. Turkiye Klinikleri J Med Sci 2005;25(6):810-6.

9. Hatfield MK, Handrich SJ, Willis JA, Beres RA, Zaleski GX. Blood patch rates after lumbar puncture with Whitacre versus Quincke 22- and 20-gauge spinal needles. AJR Am J Roentgenol 2008;190(6):1686-9. CrossRef

10. Shear T, Ahmed SU. Epidural blood patch for chronic daily headache with postural component: a case report and the review of published cases. Pain Physician 2008;11(1):77-80.

11. Ghaleb A. Postdural puncture headache. Anesthesiol Res Pract 2010;2010. pii: 102967.

12. Charsley MM, Abram SE. The injection of intrathecal normal saline reduces the severity of postdural puncture headache. Reg Anesth Pain Med 2001;26(4):301-5. CrossRef

13. Grände PO. Mechanisms behind postspinal headache and brain stem compression following lumbar dural puncture--a physiological approach. Acta Anaesthesiol Scand 2005;49(5):619-26. CrossRef

14. Camann WR, Murray RS, Mushlin PS, Lambert DH. Effects of oral caffeine on postdural puncture headache. A doubleblind, placebo-controlled trial. Anesth Analg 1990;70(2):1814. CrossRef

15. Abouleish E, Vega S, Blendinger I, Tio TO. Long-term followup of epidural blood patch. Anesth Analg 1975;54(4):459-63.

16. Richardson MG, Wissler RN. Density of lumbar cerebrospinal fluid in pregnant and nonpregnant humans. Anesthesiology 1996;85(2):326-30. CrossRef

17. Wang SC, Lirng JF, Hseu SS, Chan KH. Spontaneous intracranial hypotension treated by epidural blood patches. Acta Anaesthesiol Taiwan 2008;46(3):129-33. CrossRef

18. Gielen M. Post dural puncture headache (PDPH): a review. Reg Anesth 1989;14(3):101-6.

19. Ostheimer GW, Palahniuk RJ, Shnider SM. Epidural blood patch for post-lumbar-puncture headache. Anesthesiology 1974;41(3):307-8. CrossRef

20. Walpole JB. Blood patch for spinal headache. A recurrence and a complication. Anaesthesia 1975;30(6):783-5. CrossRef

21. Andrews PJ, Ackerman WE, Juneja M, Cases-Cristobal V, Rigor BM. Transient bradycardia associated with extradural blood patch after inadvertent dural puncture in parturients. $\mathrm{Br} J$ Anaesth 1992;69(4):401-3. CrossRef

22. Cheek TG, Banner R, Sauter J, Gutsche BB. Prophylactic extradural blood patch is effective. A preliminary communication. Br J Anaesth 1988;61(3):340-2. CrossRef

23. Desai MJ, Dave AP, Martin MB. Delayed radicular pain following two large volume epidural blood patches for postlumbar puncture headache: a case report. Pain Physician 2010;13(3):257-62. 